

MYKOLO ROMERIO UNIVERSITETAS
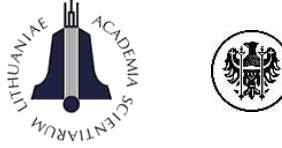

ISSN 1822-8011 (print)

ISSN 1822-8038 (online)

INTELEKTINE EKONOMIKA

INTELLECTUAL ECONOMICS

2014, Vol. 8, No. 2(20), p. 52-65

\title{
ANALYSIS OF REGIONAL INVESTMENT POSITION USING FUZZY CLUSTERS
}

\author{
Katsiaryna NAVITSKAYA \\ Yanka Kupala State University of Grodno \\ Email: navickaya@tut.by
}

doi:10.13165/IE-14-8-2-04

\begin{abstract}
The paper presents the result of investment position's evaluation of Grodno counties in 2008-2013. The concept includes the estimation of the lower level of the regional economy (17 regions and the main city Grodno). Using of fuzzy clusters lets to receive gradual transition of counties. At first we received fuzzy clusters and membership functions for regions with similar socio-economic development. Then we analyzed investment positions and value of investments of counties. In the end, we estimated the impact of investments in socio-economic development and drew some conclusions. The methodology can be used for regional investment position evaluation by investors or governance.
\end{abstract}

JEL classification: $\mathrm{C}$.

Keywords: investments, regional development, membership function, fuzzy clusters.

\section{Introduction}

Regions pay considerable attention to investment position in present time. It is connecting with increasing competitive between regions following by globalization and technologies development. The principals and methods of investment position's evaluation applied on firm's level, or state level cannot be used for regions without adaptation. Moreover, the particularities of the local region do not let to apply methods of high regional management. That is why it is actual to develop methods for local, regional evaluation.

The most important Belarusian legislations about long-term development (National Program of Socio-Economic development and National Strategy of Sustainable development) 
confirm the priority of local, regional development. Small counties are reviewed as points of national economic grows and competitive elements of the system. The increase of interest to local, regional analyzes can be proof by much research on this topic. L. Servillo and others (2012) explores territorial attractiveness for migration and it impact on the socio-economic development. J. Mawson (2007) presents the UK experience in local governance. B. Blazevic and A. Jelusic (2006) developed a model of regional economic and tourism development. National governance understands that it is necessary to promote their regions and offer much information for investors. The examples of this type of regional investment reputation or potential presentation were made by Indonesia (2014) and UAE. The evaluation of the regional investment potential of Russia is produced by The National Rating Agency (NRA) since 2007 (methodology, 2007). All of the researchers confirm that local regional development as a system consists of complex and multidiscipline problems. Moreover, the system of investment evaluation should include not only economic indexes.

The purpose of this research is to analyze by the method of fuzzy clustering the regional investment position. The following problems should be solved for this purpose: to find out the particularities of local regional investment position, to collect data and to calculate indexes, to receive fuzzy clusters with similar investment position, to compare results and make a conclusions.

The test subject area of this research is local regions of Grodno (Belarus). We analyzed regional development in 2008-2013 based on 20 indexes of 17 region and city Grodno.

The following methods were used in the research: fuzzy k-mean clustering, factor analysis, correlation analysis, principal component analysis.

Prof. M. Kovalev (2009) made the analysis of investment position of Belarus regions. However, this research used high regional level data, and the main goal is to evaluate investment activity in regions. V. Lialikova (2013) estimated life quality and competitiveness of local counties in Grodno region. She used principal component analysis for receiving the integral index and then made 4 robust clusters with homogeneous groups of regions. Presented researchers used robust methods and absence of gradual transitions led to sharp jumps of regional competitiveness rating.

In Section 1 the basic definition of the local region, regional competitiveness and investment potential and position will be clarified. In Section 2 data based on a system of indexes of regional evaluation will be collected. We will offer an analog of calculating gross regional product at local regional level. In Section 3 the method of fuzzy clustering will be described and applied to Grodno data. We will analyze membership functions and dynamic of socio-economic development. In Section 4 we will compare investment risks, potential, and capital. In the end, we will draw some conclusions.

The results of research can be interesting for investors and regional governance. The methodology can be used for regional investment position in other territories. 


\section{The Issue of Local Regional Investment Position}

Before start the analysis of regional investment position it is important to clarify the definition of basic concepts.

Firstly we should define the region and local region. In science, the region can be present in two meanings. By one meaning, the region is the territory limited by the existing administrative-territorial segmentation. By other, the region is territory limited by any signs of interrelating (population, geographical conditions and others). In this paper, the region is considered in first meaning because only administrative segmentation has authorities and opportunities to manage of socio-economic development. We will use the county for it.

Most of the countries have a multitier system of regions. Different level of regions are used for management and statistical goals. For example, European Union is divided into NUTS-1, NUTS-2, and NUTS-3 levels. Local regions correspond to the lowest level of segmentation that saved system of management. The administrative-territorial segmentation of Belarus includes 6 high counties named oblast and city Minsk. Every oblast is divided into local regions called rajon. In Belarus, there are 118 rajons including 17 in Grodno's oblast (district, ed.).

Regional competitiveness is not equivalent to the enterprises' competitiveness. When we are talking about the competitiveness of the region, we should take into account that they are not only fighters for each other because they are elements of one system. They are interesting in individual results of the local and high region the same time. Counties compete for investments and involving capitals. There are different terms of regional investment characteristics: investment climate, potential, attractiveness.

According to Asaul A. (2008) the content of the investment climate of regions includes the investment potential (existing objective conditions for investment), investment risk (assessment of business environment in terms of potential losses of investments and incomes) and investment activity (the market reaction). Investment attractiveness represents a comparative characteristic of the region (Fetisov, 2011).

We'll use term "Regional investment position". It reviews the comparable estimation of regions for investors. It can be presented as rating of regions or as a system of groups with similar investment attractiveness. Groups approach is more attractive for governance because it let to develop and apply strategies for all regions in the group.

\section{The System of Indexes for Evaluating Regional Investment Position}

Regional investment position as a complex concept should characterize by large number of different criteria combined in some groups. The structure of this system in high regional level was offered by Grishina I. (2001) and is shown in figure 1. 
Figure 1: System of criteria of regional investment position evaluation

\begin{tabular}{|c|c|c|}
\hline $\begin{array}{l}\text { Social } \\
\text { 1) migration index } \\
\text { 2) unemployment rate } \\
\text { 3) death index }\end{array}$ & \multirow{3}{*}{$\begin{array}{l}\text { Resource-labor } \\
\text { 1) percentage of } \\
\text { population in working age } \\
\text { 2) degree of young } \\
\text { population } \\
\text { 3) availability of housing } \\
\text { 4) production index } \\
\text { 5) investment index } \\
\text { 6) value of constructions } \\
\end{array}$} & \multirow{2}{*}{$\begin{array}{l}\text { Institutional } \\
\text { 1) index of retail trade and } \\
\text { cuisine objects } \\
\text { 2) index of small business } \\
\text { 3) index of small business } \\
\text { production }\end{array}$} \\
\hline \multirow{2}{*}{$\begin{array}{l}\text { Finance } \\
\text { 1) receivable (просроче) } \\
\text { 2) payables (просроч) } \\
\text { 3) degree of unprofitable }\end{array}$} & & \\
\hline & & \multirow[t]{2}{*}{$\begin{array}{l}\text { Consumer } \\
\text { 1) index of retail trade } \\
\text { 2) index of paid services }\end{array}$} \\
\hline $\begin{array}{l}\text { Ecological } \\
\text { 1) emissions per capita }\end{array}$ & $\begin{array}{l}\text { Finance } \\
\text { 1) profitability } \\
\text { 2) index of salary }\end{array}$ & \\
\hline
\end{tabular}

Source: Grishina I. (2001)

We can see that this system of indexes does not have an evaluation of agriculture development, goods turnover, high technology development and any indexes of education. We make an analysis of local counties, where are not high education institutions. We have no open data about a population with high education in local regions, and there are the very small proportion of Ph.D.'s in the region. It is confirmed that goods turnover can characterize territory development, and it is possible to add these data and the rural development indexes to the system.

We also concluded that this system of indexes is very close to the system for evaluation regional socio-economic development (Navitskaya, 2014). It's known that one of the most important criteria of socio-economic development at regional level is Gross regional product (GRP). GRP is conceptually equivalent to Gross domestic product (Vu, 2010) but in practice it is measured only by production approach and only at the highest regional level. Let's consider the final expenditure approach, and it is an adaptation to local counties level (Navitskaya \& Zhelezko, 2014). It assumes the household's and government's expenditures, investments, and net export. In the statistical collection, we can find data on investments, export and import in local, regional level. The regional government's expenditures can be measured as regional budget. Its value is enshrined in the regional legal acts approved by the local executive committees. The value of household's expenditures can be evaluated as expenditures for goods and services. We can receive the values in statistical collections as indexes of retail sales and the cost of paid services. 
For verifying our model, we calculated gross regional product at the high regional level and compared it with the official values. We applied this methodology to Belarus regions (6 oblasts and city Minsk) in 2008-2012. We received that there was a discrepancy between two values (official and calculated). But when we analyzed the degree of each region in total (for official and calculated values) and compare it with non-parametric Wilcoxon criteria we went to the conclusion that there's not a significant discrepancy between two samples. So we can use this methodology for evaluating the share of each local region in the economic reward of the high region. Thus, this index can be attested to the level of socioeconomic development of the local region.

We can assume that GRP characterizes the socio-economic development and can be used for regional investment position evaluating. GRP shows total regional potential and by dynamic analysis we can assume the availability of economic growth.

\section{The Fuzzy Clustering of Local Regions}

Fuzzy clustering is a tool for classification (grouping) of economic objects. Diaz B. and others (2006) applied it to the economy sectors and received the key sectors of the Spanish economy.

In this paper, we apply techniques based on the use of fuzzy set theory and the method of fuzzy k-means cluster analysis. The calculations were made in MS Excel. The author's software was used for the construction of membership functions.

The construction of membership functions often bases on expert opinion. It gives the share of subjectivity and requires much time. There is a method (Shtovba, 2001), which offers the construction of the membership functions using fuzzy clustering results. The algorithm is iterative and presented in figure 2. Given the large number of samples and the number of the considered criteria (in multi-dimensional analysis), the software module for constructing membership functions using the method of fuzzy c-means was developed in the language of Visual Basic for Application of MS Excel for automation of calculations.

Figure 2. The algorithm of c-mean fuzzy clusters 


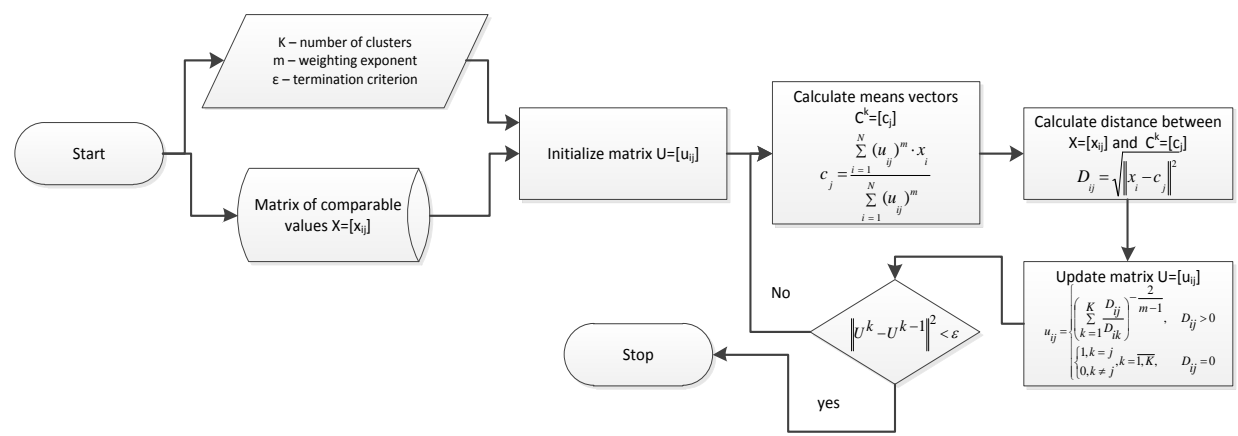

Source: author's development by Bezdek (1985) and Shahi (2011)

As we have the share of each local region in the economic reward of the high region, we divided all local region in clusters by this index firstly. One of the important questions is how many clusters should we have. In this research, we make 4 clusters. We used this number because usually city Grodno has a huge result (over 33\% of GRP), and the rest regions are divided into three groups: low, medium and a high level of socio-economic development. It is interesting to use fuzzy clusters because it is impossible instantaneous transition from one group to another. The membership function shows the degree of membership of each local region to each group. The example of the membership function is shown in the figure 3 .

Figure 3: The membership functions of fuzzy clusters of Grodno local regions in 2013.

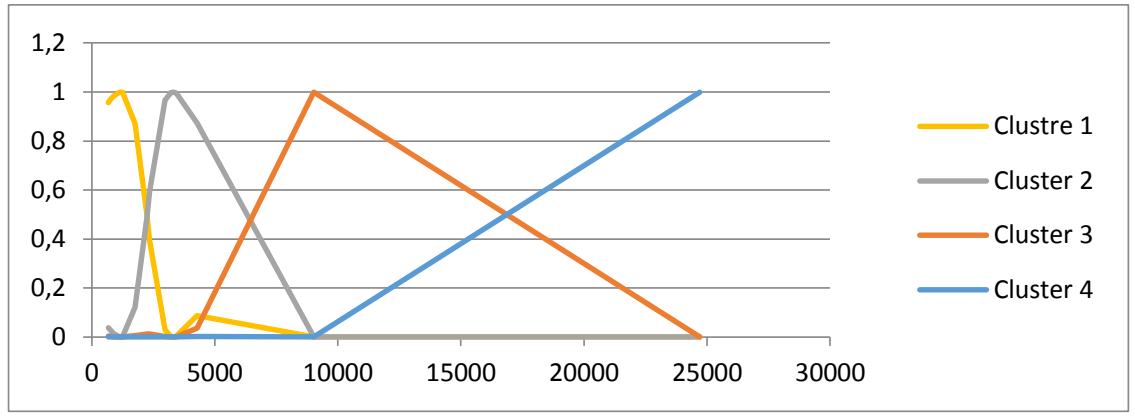

We can make a math model of each membership function for every year and compare its dynamics. For example, the transformation of the membership function for a cluster with low and medium development in 2008-2013 is shown in the figure 4 . 
Figure 4: The membership functions of first and second fuzzy cluster of Grodno local regions in 2008-2013.

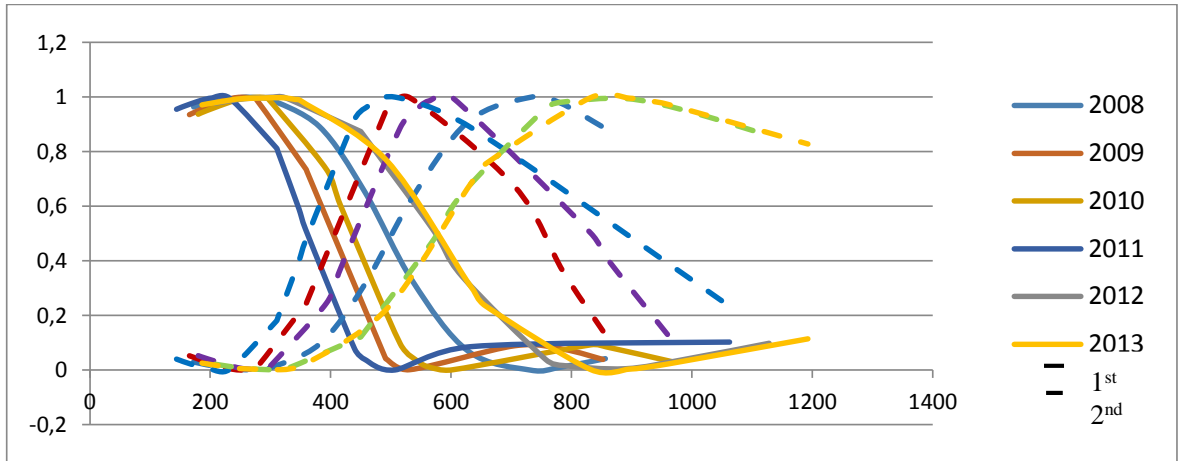

The value of GRP was adjusted by price rising coefficient. We can see that membership functions were changed in dynamics. The result, which shows $80 \%$ of the membership of the second cluster (medium development) in 2011 , is $80 \%$ of the first cluster (low development) in 2008. We can see how the financial crises of 2009 and 2011 had impacted on the economy. Moreover, we can see a good result of all regions development in 2012 and absence of real economic growth in 2013.

This type of analysis lets us make historical conclusions. We can see that Belarusian economy was not stabile last years. That is why the results of membership function compiled by all data (2008-2013) will be not so good for prediction. In the stable economy, we can use membership functions for fuzzy clusters definition by the value of GRP. We made this analysis for Grodno regions to show its possibilities. The results are shown in the figure 5.

Figure 5: The membership functions of fuzzy clusters of Grodno local regions in 2008-2013. 


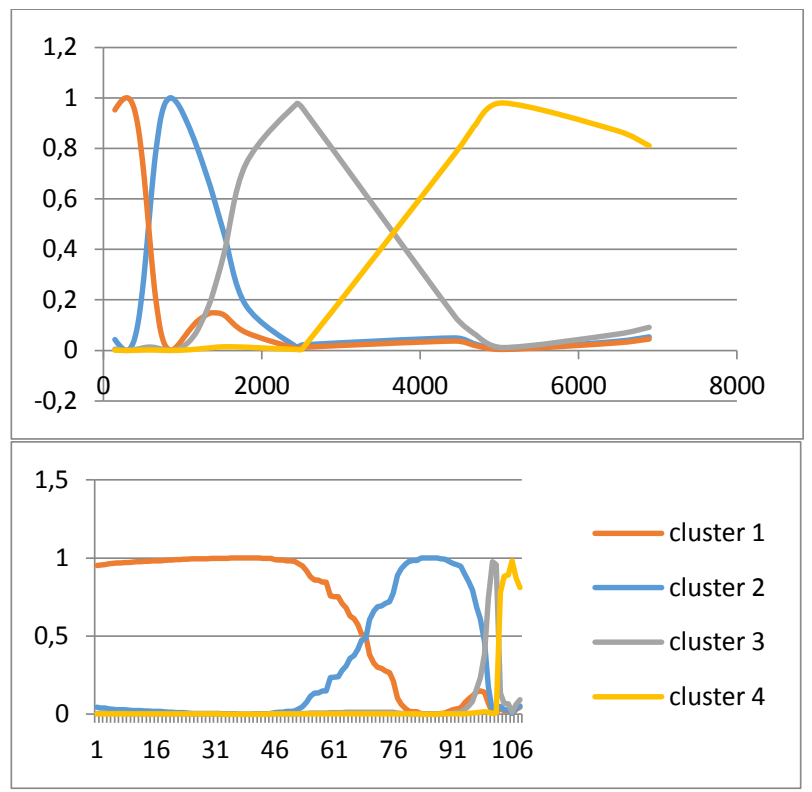

At the left figure, we can see the value of membership functions by the value of GRP, at the right - by serial number of the case. The right figure shows that most of the cases belong to clusters with low and medium development.

We can make a conclusion that over half cases belong to the low development cluster. The mathematical equations for these functions follows: 


$$
\begin{gathered}
F_{1}(x)=\left\{\begin{array}{l}
1, x \in(0 ; 360) \\
-0,0031 x+2,117, x \in(360 ; 680) \\
0, x \in(680 ; \infty)
\end{array}\right. \\
F_{2}(x)=\left\{\begin{array}{l}
0, x \in(0 ; 360) \\
0,0028 x-1,002, x \in(360 ; 715) \\
1, x \in(715 ; 840) \\
-0,0014 x+2,177, x \in(840 ; 1600) \\
0, x \in(1600 ; \infty)
\end{array}\right. \\
F_{3}(x)=\left\{\begin{array}{l}
0, x \in(0 ; 887) \\
0,0013 x-1,1531, x \in(887 ; 1650) \\
-0,00034 x+1,5612, x \in(1650 ; 4590) \\
0, x \in(4590 ; \infty)
\end{array}\right. \\
F_{2}(x)=\left\{\begin{array}{l}
0, x \in(0 ; 2300) \\
0,00042 x-0,95231, x \in(2300 ; 4650) \\
1, x \in(4650 ; \infty)
\end{array}\right.
\end{gathered}
$$

The research confirms that there is a high degree of differentiation of Grodno's local regions development. Only Lida's region's development corresponded to the high-level development cluster in 2008-2012. However, a good sign is that Volkovysks's region has an attachment to this cluster (not more than 0,24) in 2010,2012 and Smorgon's region belongs to it in 2012 for 0,07 .

Using this formula we can calculate in future the membership functions value based on GRP adjusted for price growth index.

\section{Analysis of regional investment potential, risks and value of investments.}

Investment position of the region it is competitive and comparative evaluation of its investment climate. Above it was noted that investment climate included potential, risks and value of investments. We can represent it on the graph. For this aim, the indexes of investment potential, risk, and value of investments were calculated for local counties of Grodno Region in 2012 by the methodology of Grishina I. (2001). The results are presented in figure 6 . 
Figure 6. Investments potential, risks and value for Grodno's counties in 2012.

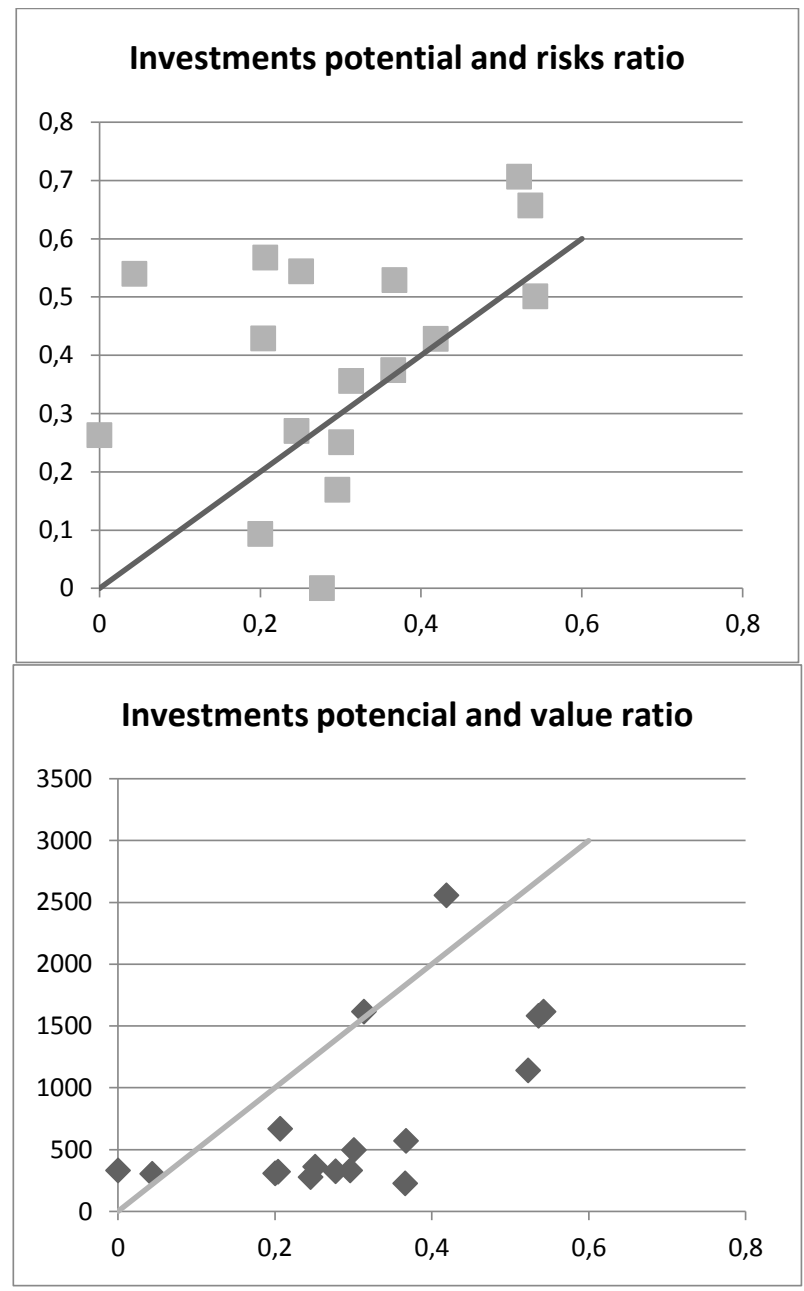

The diagonal shows the balance between potential and risk and potential and value of investments.

The place of regions above the diagonal on left figure denotes that the value of risks exceeds the potential of the county. The regions that are place below the diagonal are more attracted for investors. 
The place of regions above the diagonal on right figure means that region attracts more investments than its investment potential lets. It can be connected with traditional centers of investments, better regional branding policy and greater recognition. Unfortunately most of the local counties of Grodno region place below the balance line. The value of investments is significantly less that the value that has an impact on socio-economic development. We can make a conclusion that Grodno's local regions do not use their potential totally. They should strengthen their promotion and be more active in world competition for investments.

But not only current situation is important for investment position analysis. That is why we need to add the growth rate of investment. As regions are participants of competitive battle and the same time, they are constituents of the high region. We can adopt the methodology of Boston Consulting group (Botti L., 2012) and to apply it to Grodno's counties evaluation. Market share is the share of regional investments, and the county's share is the impact of the region in the gross regional product of high regional development. The results are presented in figure 7 .

Figure 7. Regional investment share of Grodno's counties in 2009-2013.

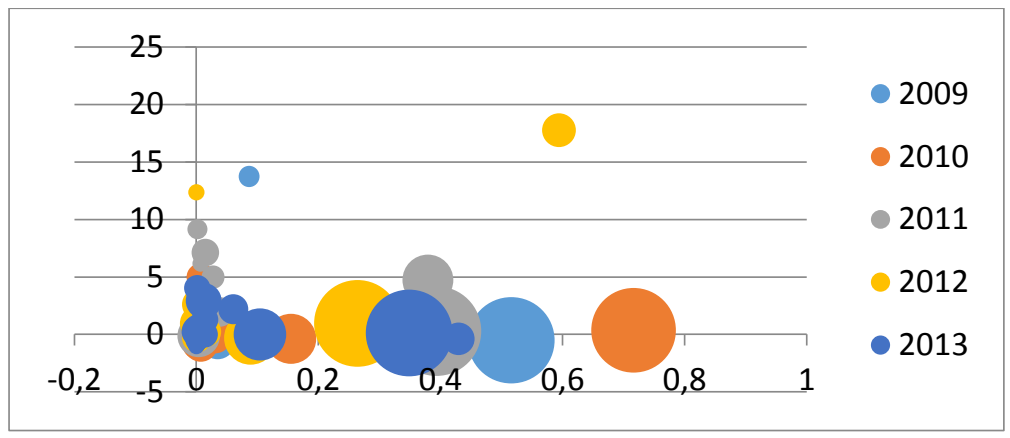

We excluded from this analysis 2 cases when the value of investments index were more than $20000 \%$. The analysis sets that most of the regions received the small value of investments. Huge investments projects are seldom and short-term. Only city Grodno attracts big amounts every year. There's only one case when the region received a big share of investments and high growth rate (point in the right top corner). It was connected with new plant opening. It means that regions have not innovation and investment injections, allowing the lead to future economic growth.

We can proof that investments influence on regional economic growth. We analyzed the correlation between the value of investments and GRP (both in real prices) and received very strong dependence (more than 0.9 ). We can also claim that there's a time lag of 
investments influence (in 2 years correlation become stronger). The model of GRP $\left(\mathrm{R}^{2}=0,954\right)$ is:

$$
G R P=-48,3714+3,7464 \cdot I_{t-2}
$$

It means that investments lead to regional growth and have a long-term effect. However, at most of the cases the value of investments corresponds to the population and doesn't bring boost effects. We can conclude that investment activity in Grodno counties is sporadic with seldom cases of major projects. Most of the investments are involved in Grodno city, but there's not a significant increase in the rate of investments growth.

\section{Conclusion}

The method of fuzzy clustering was applied to regional investment position evaluation. This allows receiving the affiliation of each region to groups of different level of investment attractiveness.

The estimation was made based on a system of indexes including criteria of potential and risks. The integral criterion of regional development (analog of GRP) was calculating and regions were selected to groups based on it.

The local regional economy can characterize by strong correlation dependence between indexes of population, investments and GRP. The local regional development in Belarus can be characterized only as industrial and labor-intensive. Grodno's counties have not system policy of investments attracting.

There're inequalities in regional socio-economic development and investment positions. Most local regions have a low and medium contribution to the socio-economic development and are not attractive to investors. In order to change this situation, the government should promote local counties and create investment infrastructure.

The using of fuzzy clusters in the investment position analysis can show the gradual transition of regions. It is possible to make a historical analysis based on this method or analyze factors of local regions evolution.

\section{References}

1. Aivazyan, S. (2001) Межстрановой анализ интегральных категорий качества жизни населения (эконометрический подход) (60). М.: ЦЭМИ РАН.

2. Asaul A. \& Karpov B. \& Perebyazkin V. \& Starovoitov M. (2008) Модернизаџия экономики на основе технологических инноваџий (606). СПб: АНО ИПЭВ.

3. Barkley, D. and Dudensing R.M. (2011) Industrial Legacy Matters: Implications for the Development and Use of Indices of Regional Competitiveness. Economic Development Quarterly, vol. 25: pp. 130 - 142. 
4. Blaževic, B. and Jelušic A. (2006) Modelling regional economic development. Kybernetes, Vol. 35 Iss 7/8: pp. $1190-1202$.

5. Botti, L. \& Goncalves O. \& Ratsimbanierana H. (2012) French Destination Efficiency: A Mean- Variance Approach. Journal of Travel Research, №51 (n.2): pp.115-129.

6. Diaz, B. and Moniche, L. and Morillasa, A. (2006) Fuzzy Clustering Approach to the Key Sectors of the Spanish Economy. Economic Systems Research, Vol. 18, No. 3: pp. $299-318$.

7. Fetisov, G. (2011) Методы оценки инвестиционного климата регионов России и пути его улучшения. Центр дистанционного образования. Retrieved September 21, 2014 from http://www.elitarium.ru/2011/05/30/ocenka_investicionnogo_klimata.html.

8. Grishina I \& Shahnazarov A \& Rojzman I. (2001) Комплексная оценка инвестиционной привлекательности и инвестиционной активности российских регионов: методика определения и анализ взаимосвязей. Инвестиции в России. Retrieved September 21, 2014 from http://www.ivrv.ru/2001/rus/p0104/p010402.htm.

9. Kovalev M. \& Shashko А. (2009) Инвестиционная активность в регионах Республики Беларуси и пути ее повышения. Вестник ассоциации белорусских банков, № 2: pp. 8-27.

10. Lialikova, V. and Maskolus A. (2013) Конкурентоспособность регионов Республики Беларусь: основные факторы и методика оценки. Проблемы развития экономики и сферы сервиса в регионе (77-80). Сыктывкар: Материалы VII Междунар. науч.-практ. конф.

11. Mawson, J. (2007). Regional governance in England: past experience, future directions?. International Journal of Public Sector Management, Vol. 20 Iss 6: pp. 548 - 566.

12. The methodology of remote rating of investment attractiveness of regions (2007). National rating agency. Retrieved April 11, 2014 from http://www.ranational.ru/ratings/regions/regions-raiting-investment/regions-invest-metodology-2014/.

13. Navitskaya, K. (2014) Основные факторы прогнозирования ВРП Гродненской области. Экономика и управление, №1: pp.111-115.

14. Navitskaya, K. \& Zhelezko, B. (2014) Прогнозирование показателей социально-экономического развития районов Гродненской области. Экономика, право и проблемы управления: сб. науч. трудов №4 (под общ. ред. В.Г. Тихини). Минск: Частн. ин-т упр. и предпр., 2014: pp. 159- 167.

15. Regional investment potential (SIPID) (2014). Investment Coordinating Board of the Republic of Indonesia. Retrieved May 12, 2014 from http://www.bkpm.go.id/contents/general/117203/regional-investment-potentialsipid\#.VJHew3uEc2d.

16. Servillo, L. and Atkinson, R. and Russo, A.P. (2012) Territorial attractiveness in EU urban and spatial policy: a critical review and future research agenda. European Urban and Regional Studies, vol. 19, 4: pp. 349-365. 
17. Shtovba, S. (2001) Введение в теорию нечетких множеств и нечеткую логику. Matlab \& toolboxes. Retrieved April, 15, 2013 from http://matlab.exponenta.ru/fuzzylogic/book1/index.php

18. Vu Quang Viet (2010) Gross regional product (GRP): an introduction. United Nations Statistics Division. Retrieved August 12, 2013 from http://unstats.un.org/unsd/economic_stat/China/background_paper_on__GRP.pdf

\section{About the Author:}

Navitskaya KATSIARYNA - Yanka Kupala State University of Grodno, The faculty of economics and management.

Research fields: economics, business, investment. 